\title{
Knowledge and Skills of Using Frog VLE among Primary School Students in Mathematics Learning
}

Siti Nur Akma Mat Isa \& Siti Mistima Maat

To Link this Article: http://dx.doi.org/10.6007/IJARBSS/v11-i5/10006

DOI:10.6007/IJARBSS/v11-i5/10006

Received: 01 March 2021, Revised: 05 April 2021, Accepted: 28 April 2021

Published Online: 25 May 2021

In-Text Citation: (Isa \& Maat, 2021)

To Cite this Article: Isa, S. N. A. M., \& Maat, S. M. (2021). Knowledge and Skills of Using Frog VLE among Primary School Students in Mathematics Learning. International Journal of Academic Research in Business and Social Sciences, 11(5), 525-536.

\section{Copyright: (c) 2021 The Author(s)}

Published by Human Resource Management Academic Research Society (www.hrmars.com)

This article is published under the Creative Commons Attribution (CC BY 4.0) license. Anyone may reproduce, distribute, translate and create derivative works of this article (for both commercial and non-commercial purposes), subject to full attribution to the original publication and authors. The full terms of this license may be seen at: http://creativecommons.org/licences/by/4.0/legalcode

Vol. 11, No. 5, 2021, Pg. 525 - 536

Full Terms \& Conditions of access and use can be found at http://hrmars.com/index.php/pages/detail/publication-ethics 


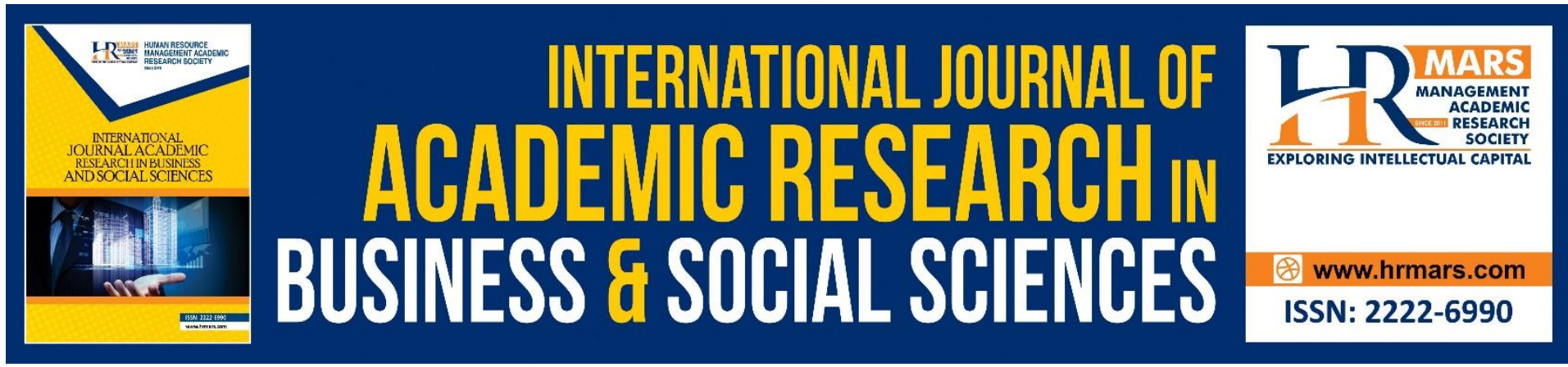

\title{
Knowledge and Skills of Using Frog VLE among Primary School Students in Mathematics Learning
}

\author{
Siti Nur Akma Mat Isa \& Siti Mistima Maat \\ Research Center of Teaching and Learning Innovations Faculty of Education \\ Universiti Kebangsaan Malaysia \\ Email: sitimistima@ukm.edu.my
}

\begin{abstract}
Frog VLE is an educational innovation that uses multimedia materials to support student learning. The purpose of this study was to determine students' knowledge and skills regarding the use of Frog VLE in mathematics learning. 150 fifth-year students were chosen at random to be the respondents of the study. The research instrument is a set of questionnaires with consist of three constructs that include knowledge, skills, and use of the Frog VLE. The descriptive statistics, t-test, and Pearson correlation were used to analyse the data which was conducted using SPSS 23.0 software. The findings of this study revealed that Frog VLE knowledge and skills are at a moderate level among the respondents. The t-test result indicated that there was a significant difference in knowledge of how to use Frog VLE based on gender, but there was no significance difference in skills of how to use Frog VLE based on gender. Pearson correlation test results show a strong and significant positive relationship between Frog VLE knowledge and skills and Frog VLE use in mathematics learning. The findings show that the greater a student's knowledge and skills of Frog VLE, the greater his or her use of Frog VLE in mathematics learning. These implies that using ICT in mathematics teachings requires students' knowledge in skill in order to enhance students' learning.
\end{abstract}

Keywords: Knowledge, Mathematics, Learning, Primary, Students

\section{Introduction}

The use of technology in mathematics learning in accordance with 21st-century learning is seen in improving students' thinking skills and mathematical achievement. Furthermore, more creative learning and facilitation practises with technology integration, which is one of the transformations and innovations in education today, are highly emphasised in education. Frog VLE has been introduced in Malaysia as one of the new strategies in 21st-century learning aimed at assisting today's students in acquiring information, developing individual potential, and utilising technology in learning (Ummu Salma \& Fariza 2014).

In this digital age, the use of Frog VLE in teaching and learning will be able to increase interest and stimulate students' (Ashikin \& Kamisah 2017). Educators must therefore integrate the use of Frog VLE with discovery inquiry-based learning strategies, problem-based learning, 
cooperative learning, blended learning (virtual learning and face-to-face learning), and project-based learning (Ashikin \& Kamisah 2017; Shahfiezul \& Fariza 2016).

Individuals with a high level of computer literacy will be able to use Frog VLE as good and effective teaching and learning media. Knowledge is the input gained by a person through experience, formal or informal education, and cognitive processes. While skills are the ability to do something (manual or physical) well, acquired through training or learning, competence or ingenuity in doing something is also a skill (Lepp et al., 2021). As a result, students who are familiar with and skilled at using Frog VLE will be able to take advantage of ICT by self-learning and collaborating with peers prior to the learning session. This indicates that the use of Frog VLE will increase if the knowledge and skills of Frog VLE increase.

This is consistent with the findings of Zaira et al. (2016), who discovered a significant positive relationship between the level of ICT skills and the level of use of Frog VLE. Some researchers investigate gender differences in knowledge and use of ICT and Frog VLE. According to the previous research, female respondents have a higher level of knowledge and use of Frog VLE than male respondents. There was a significant difference in the level of VLE Frog use among teachers who teach based on gender, with female teachers using VLE Frog at a higher rate than male teachers. Based on the literature, the study's trend show only teachers, university students, and secondary school students were involved as the respondents. Obtaining respondents amonhg primary school students for the study is rather challenging especially in understanding the level and application of ICT among them.

Learning using Frog VLE helps students more meaningfully understand the concept of learning, because it encourages students to visualise, think and remember in long term memory. However, even after the teacher has told you that some students do not use and do not use the application. This can be due to the skills and the knowledge to use the Frog VLE application and the ICT and Frog VLE app itself.While the ICT application in education and learning is highlighted by the national agenda, statistics on the use of Frog VLE by students are not positive. There remain weaknesses and problems in the Frog VLE implementation as regards the implementation of schools, including limited Internet access, lack of ICT skills, lack of oversight, insufficient time and a large amount of workload in rural schools, teachers and students (Norazilawati et al., 2013; Nor Zaira et al., 2016). The Kelantan VLE 2017 data analysis shows that the use of Frog VLE has declined (BTPN 2017). Data demonstrate that students don't use Frog VLE to achieve the set KPIs. In general statistics, the level of utilisation of the virtual learning environment indicates that it is too low. This raises the question, is it not due to a lack of knowledge and abilities in the use of Frog VLE that FrogVLE is used? The reason why Ummu Salma and Fariza (2016) have concluded this is because the lack of knowledge about Frog VLE means that teachers do not use Frog VLE in learning and facilitation.

Therefore, researchers would like to test whether knowledge and skills differ from gender-based ICT-based students using the Frog VLE in mathematical learning in the context of this study.

Specifically, the objectives to be achieved in this study are to:

- identify the level of knowledge and skills of Frog VLE and the use of Frog VLE fifth-year students in learning mathematics.

- determine differences in the knowledge and skills of using Frog VLE fifth-year students based on gender. 
- determine the relationship between Frog VLE knowledge and skills with the use of Frog VLE in mathematics learning.

\section{Methodology}

A quantitative survey design was used of which 150 primary school students were selected using stratified random sampling. There were students of rural schools in Machang district, Kelantan, are the target population of this study. In the first stage of the project the researcher selects a school randomly from every zone in the study district, of which 30 students from each selected school were selected.

The validity and reliability of the scores can further be increased with a large score. In this study, information on the Frog VLE usage by primary school students is collected and analysed using a questionnaire-shaped instrument since it is easy to administer and easiest to manage. There are three sections in the questionnaire used in this study: sections $A, B$ and C. Section A includes issues relating to the demographics of students. Part B includes 8 items related to Frog VLE knowledge and skills.

The use of Frog VLE in mathematics of 10 subjects is related to Part C. The questionnaire items used have been adapted and amended based on the Education Technology Division questionnaires. For the measurement scale for this Part B and C questionnaire, options 1 (strongly disagreement) 2 (unknown or uncertain), 3 (unknown or uncertain), 4 (accepting) and 5 are measured by 5 points (strongly agree).

The use of Frog VLE in mathematics of 10 subjects is related to Part C. The questionnaire items used have been adapted and amended based on the Education Technology Division questionnaires. For the measurement scale for this Part B and $C$ questionnaire, options 1 (strongly disagreement) 2 (unknown or uncertain), 3 (unknown or uncertain), 4 (accepting) and 5 are measured by 5 points (strongly agree). A pilot study involving 40 participants who have the same characteristics as the study population was carried out not only to ensure the validity and reliability of the instrument. This pilot study is also important to test the understanding of the questionnaire items by the respondents before conducting the actual study. Data from the pilot study were analysed and it was found that all items were of high validity. Next, it was found that the Frog VLE Usage Knowledge Construct Cronbach Alpha rReliability Index was $0.736,0.772$, and 0.896 were Frog VLE Using Construction. This demonstrates the high reliability of the tool in this study. The reliability index $\alpha$ of Cronbach Alpha is higher than 0.70. This results in good inner stability and consistency of the questionnaire items in this study (Pallant 2001). Therefore, the results of the pilot study show that this instrument can be used for real research to measure the level of knowledge, skills, and use of Frog VLE students.

The level of knowledge, skills, and use of Frog VLE was measured using a mean score. The mean score of each variable used in the questionnaire instrument is interpreted according to the interpretation proposed by Kamaruzaman (2009) as in Table 1. 
Table 1: Mean score interpretation scale

\begin{tabular}{cl}
\hline Mean & Interpretation \\
$\mathbf{1 . 0 0 - 1 . 8 0}$ & Very low \\
$\mathbf{1 . 8 1}-\mathbf{2 . 6 0}$ & low \\
$\mathbf{2 . 6 1}-\mathbf{3 . 4 0}$ & Average \\
$\mathbf{3 . 4 1}-\mathbf{4 . 2 0}$ & High \\
$\mathbf{4 . 2 1}-\mathbf{5 . 0 0}$ & Very high \\
\hline
\end{tabular}

All data of this study were analyzed using descriptive and inferential statistics using SPSS software version 23.0. To answer the research question for objective 1 , descriptive analysis involving frequency, the mean, and standard deviation were used, while inference analysis involving t-test was used for objective 2 and Pearson correlation for objective 3. Statistical assumptions for conducting inference tests were executed prior to data analysis process.

\section{Findings}

\section{Demographics of Respondents}

According to the demographics of the study respondents, there were a total of 150 respondents, with 72 male students (48\%) and 78 female students (52\%). However, one of the study's limitations is that all of the respondents are Malay students.

Table 2: Profile of respondents

\begin{tabular}{lll}
\hline Factor & Category & \\
\hline Gender & Male(48\%) & Female (52\%) \\
$\begin{array}{l}\text { Mathematics teachers use Frog VLE in } \\
\text { teaching and learning }\end{array}$ & No (100\%) \\
There are computer and internet facilities & Yes (65.3\%) & No (34.7\%) \\
\hline According to the descriptive analsis, themathentics teachers of the respondents do not
\end{tabular}

According to the descriptive analysis, the mathematics teachers of the respondents do not use Frog VLE as one of the ways to make learning and facilitation more creative and interesting. According to the study, 65.3 percent of respondents have access to a computer and the internet at home. While 34.7 percent of them stated that they do not have access to a computer or the internet at home.

\section{Level of Knowledge Analysis of Frog VLE}

Table 3 represents the analysis of fifth-year students' Frog VLE knowledge level. The findings show that the highest mean score for item B2 is 4.03 , with 49.3 percent of respondents stating that they know and understand how to use the Frog VLE as described by the teacher. While item B4 has the lowest mean score of 2.63, 41 respondents stated that they do not know how to use Frog VLE outside of school hours. The overall mean score analysis is 3.30 , indicating that fifth-year students have a moderate understanding of Frog VLE. 
Table 3: Analysis of knowledge level on Frog VLE

\begin{tabular}{|c|c|c|c|c|c|c|c|}
\hline No. Item & $\begin{array}{c}\text { Strongly } \\
\text { Disagree } \\
\mathbf{f} \\
(\%) \\
\end{array}$ & $\begin{array}{c}\text { Disagree } \\
\text { Bil } \\
f \\
(\%) \\
\end{array}$ & $\begin{array}{c}\text { Uncertain } \\
f \\
(\%)\end{array}$ & $\begin{array}{c}\text { Agree } \\
\text { Bil } \\
f \\
(\%) \\
\end{array}$ & $\begin{array}{c}\text { Strongly } \\
\text { Agree } \\
\text { f } \\
(\%) \\
\end{array}$ & & \\
\hline B1 & $\begin{array}{c}29 \\
(19.3)\end{array}$ & $\begin{array}{c}39 \\
(26.0)\end{array}$ & $\begin{array}{c}36 \\
(24.0)\end{array}$ & $\begin{array}{c}33 \\
(22.0)\end{array}$ & $\begin{array}{c}13 \\
(8.7)\end{array}$ & & \\
\hline B2 & $\begin{array}{c}7 \\
(4.7)\end{array}$ & $\begin{array}{c}6 \\
(4.0)\end{array}$ & $\begin{array}{c}13 \\
(8.7)\end{array}$ & $\begin{array}{c}74 \\
(49.3)\end{array}$ & $\begin{array}{c}50 \\
(33.3)\end{array}$ & & \\
\hline B3 & $\begin{array}{c}9 \\
(6.0)\end{array}$ & $\begin{array}{c}11 \\
(7.3)\end{array}$ & $\begin{array}{c}18 \\
(12.0)\end{array}$ & $\begin{array}{c}66 \\
(44.0)\end{array}$ & $\begin{array}{c}46 \\
(30.7)\end{array}$ & & \\
\hline B4 & $\begin{array}{c}39 \\
(26.0)\end{array}$ & $\begin{array}{c}41 \\
(27.3)\end{array}$ & $\begin{array}{c}22 \\
(14.7)\end{array}$ & $\begin{array}{c}32 \\
(21.3)\end{array}$ & $\begin{array}{c}16 \\
(10.7)\end{array}$ & & \\
\hline B5 & $\begin{array}{c}12 \\
(8.0)\end{array}$ & $\begin{array}{c}21 \\
(14.0)\end{array}$ & $\begin{array}{c}53 \\
(35.3)\end{array}$ & $\begin{array}{c}45 \\
(30.0)\end{array}$ & $\begin{array}{c}19 \\
(12.7)\end{array}$ & & \\
\hline \multicolumn{6}{|c|}{ Overall Mean } & $\begin{array}{c}3.30 \\
(0.72)\end{array}$ & Medium \\
\hline
\end{tabular}

\section{Pupil Skill Level Analysis of Frog VLE}

Table 4 shows the analysis of skill levels on Frog VLE students. Findings show that the highest mean score is 3.06 for items B7 and B8. The overall mean score indicates that the level of skill of fifth-year students using Frog VLE is at a moderate level (mean $=2.92, \mathrm{SD}=0.98$ ). This means that students' skills to use the applications found in Frog VLE are at a moderate level.

Table 4: Skill level analysis of Frog VLE

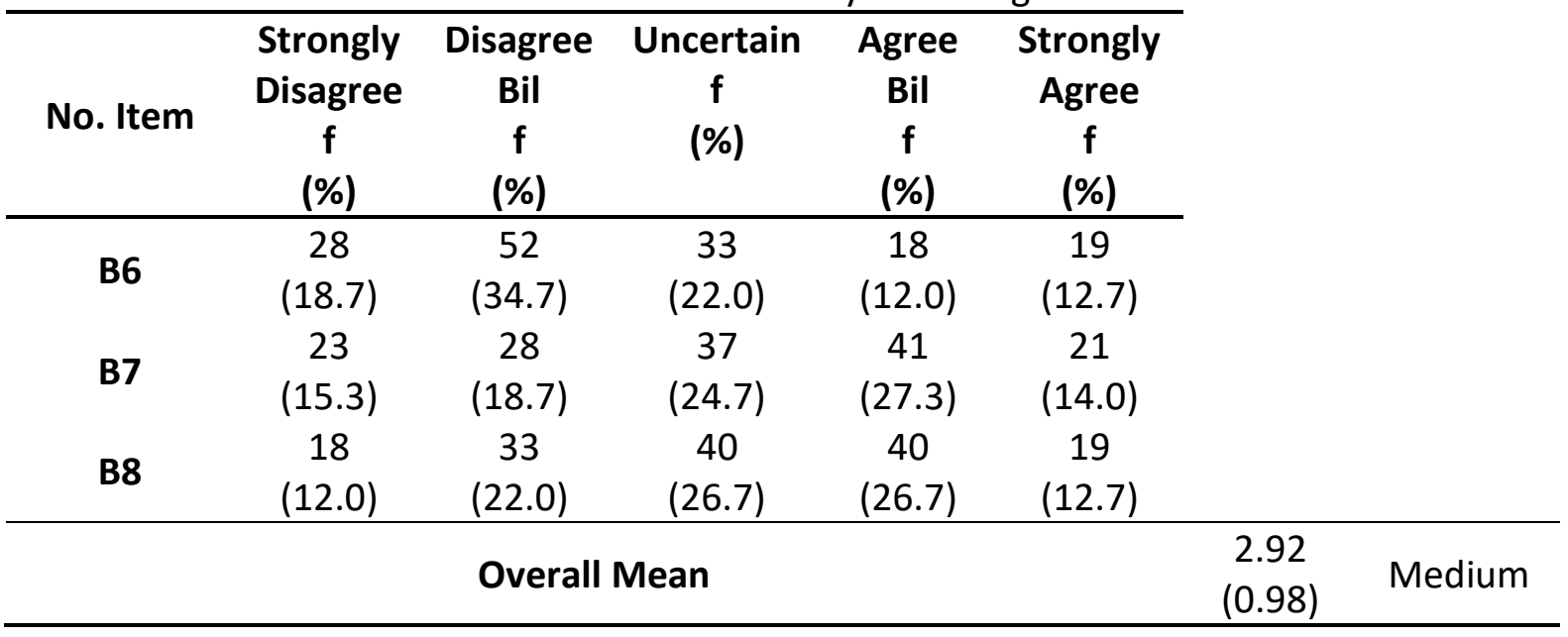

\section{Analysis of the Level of Use of Frog VLE in Mathematics Learning}

The analysis reveals that the highest mean score is 4.27 for item C9, where students use learning materials in the Frog application to learn mathematics because it is interesting. The lowest mean score is $\mathbf{2 . 6 7}$ for item C2, where students use less Frog VLE to interact with teachers about learning mathematics. Overall, the analysis revealed that Frog VLE students use mathematics learning at a moderate level. (mean $=3.51, \mathrm{SD}=0.68)$. 
Table 5: Analysis of the level of use of Frog VLE in mathematics learning

\begin{tabular}{|c|c|c|c|c|c|c|c|}
\hline No. Item & $\begin{array}{c}\text { Strongly } \\
\text { Disagree } \\
f \\
(\%)\end{array}$ & $\begin{array}{c}\text { Disagree } \\
\text { Bil } \\
f \\
(\%)\end{array}$ & $\begin{array}{c}\text { Uncertain } \\
f \\
(\%)\end{array}$ & $\begin{array}{c}\text { Agree } \\
\text { Bil } \\
f \\
(\%)\end{array}$ & $\begin{array}{c}\text { Strongly } \\
\text { Agree } \\
\text { f } \\
(\%)\end{array}$ & $\begin{array}{c}\text { Strongly } \\
\text { Disagree } \\
f \\
(\%)\end{array}$ & \\
\hline $\mathrm{C} 1$ & $\begin{array}{c}25 \\
(16.7)\end{array}$ & $\begin{array}{c}38 \\
(25.3)\end{array}$ & $\begin{array}{c}49 \\
(32.7)\end{array}$ & $\begin{array}{c}15 \\
(10.0)\end{array}$ & $\begin{array}{c}23 \\
(15.3)\end{array}$ & $\begin{array}{c}2.82 \\
(1.27)\end{array}$ & \\
\hline $\mathrm{C} 2$ & $\begin{array}{c}26 \\
(17.3)\end{array}$ & $\begin{array}{c}43 \\
(28.7)\end{array}$ & $\begin{array}{c}47 \\
(31.3)\end{array}$ & $\begin{array}{c}22 \\
(14.7)\end{array}$ & $\begin{array}{c}12 \\
(8.0)\end{array}$ & $\begin{array}{c}2.67 \\
(1.16)\end{array}$ & \\
\hline C3 & $\begin{array}{c}21 \\
(14.0)\end{array}$ & $\begin{array}{c}21 \\
(14.0)\end{array}$ & $\begin{array}{c}55 \\
(36.7)\end{array}$ & $\begin{array}{c}36 \\
(24.0)\end{array}$ & $\begin{array}{c}17 \\
(11.3)\end{array}$ & $\begin{array}{c}3.05 \\
(1.18)\end{array}$ & \\
\hline C4 & $\begin{array}{c}13 \\
(8.7)\end{array}$ & $\begin{array}{c}23 \\
(15.3)\end{array}$ & $\begin{array}{c}48 \\
(32.0)\end{array}$ & $\begin{array}{c}47 \\
(31.3)\end{array}$ & $\begin{array}{c}19 \\
(12.7)\end{array}$ & $\begin{array}{c}3.24 \\
(1.13)\end{array}$ & \\
\hline C5 & $\begin{array}{c}11 \\
(7.3)\end{array}$ & $\begin{array}{c}17 \\
(11.3)\end{array}$ & $\begin{array}{c}49 \\
(32.7)\end{array}$ & $\begin{array}{c}51 \\
(34.0)\end{array}$ & $\begin{array}{c}22 \\
(14.7)\end{array}$ & $\begin{array}{c}3.37 \\
(1.10)\end{array}$ & \\
\hline C6 & $\begin{array}{c}7 \\
(4.7)\end{array}$ & $\begin{array}{c}20 \\
(13.3)\end{array}$ & $\begin{array}{c}28 \\
(18.7)\end{array}$ & $\begin{array}{c}47 \\
(31.3)\end{array}$ & $\begin{array}{c}48 \\
(32.0)\end{array}$ & $\begin{array}{c}3.73 \\
(1.18)\end{array}$ & \\
\hline $\mathrm{C7}$ & $\begin{array}{c}1 \\
(0.7)\end{array}$ & $\begin{array}{c}8 \\
(5.3)\end{array}$ & $\begin{array}{c}35 \\
(23.3)\end{array}$ & $\begin{array}{c}63 \\
(42.0)\end{array}$ & $\begin{array}{c}43 \\
(28.7)\end{array}$ & $\begin{array}{c}3.93 \\
(0.89)\end{array}$ & \\
\hline C8 & $\begin{array}{c}4 \\
(2.7)\end{array}$ & $\begin{array}{c}9 \\
(6.0)\end{array}$ & $\begin{array}{c}25 \\
(16.7)\end{array}$ & $\begin{array}{c}61 \\
(40.7)\end{array}$ & $\begin{array}{c}51 \\
(34.0)\end{array}$ & $\begin{array}{c}3.97 \\
(0.99)\end{array}$ & \\
\hline C9 & $\begin{array}{c}3 \\
(2.0)\end{array}$ & $\begin{array}{c}5 \\
(3.3)\end{array}$ & $\begin{array}{c}11 \\
(7.3)\end{array}$ & $\begin{array}{c}61 \\
(40.7)\end{array}$ & $\begin{array}{c}70 \\
(46.7)\end{array}$ & $\begin{array}{c}4.27 \\
(0.89)\end{array}$ & \\
\hline C10 & $\begin{array}{c}3 \\
(2.0) \\
\end{array}$ & $\begin{array}{c}4 \\
(2.7)\end{array}$ & $\begin{array}{c}27 \\
(18.0)\end{array}$ & $\begin{array}{c}67 \\
(44.7)\end{array}$ & $\begin{array}{c}49 \\
(32.7)\end{array}$ & $\begin{array}{c}4.03 \\
(0.89)\end{array}$ & \\
\hline \multicolumn{6}{|c|}{ Overall Mean } & $\begin{array}{c}3.51 \\
(0.68)\end{array}$ & Medium \\
\hline
\end{tabular}

\section{Analysis of Knowledge Differences in Year Five Students Based on Gender}

A T-test of two independent samples was conducted to test the mean difference of knowledge between male students and fifth-year female students. Through the t-test of two independent samples conducted, there was a significant difference between the mean knowledge of male students (mean $=3.17, \mathrm{SD}=0.73$ ) with female students (mean $=3.43, \mathrm{SD}$ $=0.7$ ) with $\mathrm{t}(148)=-2.216, \mathrm{p}<0.05$. This shows that fifth-year female students have better knowledge in Frog VLE than fifth-year male students. While the effect size equals 0.36 . This value according to Cohen (1988) is moderate in the difference magnitude. Thus gender affects the difference in the mean score of moderate knowledge for women compared to men.

\section{Analysis of Differences in the Skills of Year Five Students Based on Gender}

An independent t-test analysis was conducted to determine the difference in the mean skills of fifth-year students on Frog VLE between male and female students. The results of t-test analysis found that there was no significant difference in the mean of students' skills on Frog VLE between male students (mean $=2.79, S D=1.04$ ) and female students (mean $=3.05, S D=$ 0.91 ), with a value of $t(148)=-1.659, p>0.05$. This means that the skills of Frog VLE male and female students are at the same level that is at a moderate level. The size effect calculated using the square ETA shows a small magnitude difference of 0.27 which indicate an svergse 


\section{Analysis of the Relationship Between Knowledge and Skills with the Use of VLE Frog in Mathematics Learning}

Pearson correlation analysis was used to test the relationship between students' Frog VLE knowledge and skills with the use of Frog VLE in mathematics learning. The results of the analysis using Pearson correlation showed that there was a significant relationship between knowledge with the use of Frog VLE $(r=0.485, p<0.01)$ and skills with the use of Frog VLE ( $r$ $=0.531, p<0.01)$. For the knowledge variable, the value of the correlation coefficient, $r=$ 0.485 indicates that there is a moderate positive relationship (Cohen 1988) between the knowledge of Frog VLE application with the use of Frog VLE in mathematics learning. As for the skill variable, the value of the correlation coefficient, $r=0.531$ indicates that there is a strong positive relationship (Cohen 1988) between Frog VLE application skills with the use of Frog VLE in mathematics learning. This implies that the higher the students' knowledge and skills of the Frog VLE application, the higher their tendency to use Frog VLE in learning, and vice versa.

\section{Discussion}

\section{Levels of Knowledge, Skills, and Use of Frog VLE in Mathematics Learning}

This study was aimed at identifying the skills and knowledge in the use of Frog VLE in mathematics learning by primary school students. The results show that primary school students have a moderate level of expertise and knowledge with regard to Frog VLE. This demonstrates that students must still be guided in their efforts to improve their knowledge and skills so that they can use Frog VLE to support their mathematics training. These results also mean that while the proportion of respondents who agree to understand Frog VLE as a teacher is high, Frog VLE knowledge is still moderate. This may be because the content of the description by the teacher does not take the application into account in mathematics learning. Teachers must therefore explain students in more detail about Frog VLE while promoting activities by Frog VLE.

In addition, teachers may still not stress the use of frog VLE in their teaching due to the moderate level of knowledge of students. The results of this study show that during teaching and learning teachers do not use the Frog VLE application. A study by Mahizer and Mohd Azli (2016) indicated that teachers agree to be more independent and able to find their information after the introduction of Frog VLE into a classroom and to participate in the cooperation and efficiency of learning successfully. In the meantime, ICT knowledge of teachers also has an effect on the implementation of ICT learning. The result of a study by Romero-Tena et al. (2020) which found that the proportion of trainee teachers who are unknown to ICTs is quite high.

In addition, Frog VLE can be moderated by students due to their know-how in Frog VLE. His skills therefore also correspond to his knowledge. This means that students must still be exposed to the teacher's mentoring skills to use Frog VLE. The results of this study are consistent with the study by (Kindsiko et al., 2020), which shows that the level of computer and ICT teacher skills is still modest. Study respondents may use computers and ICTs only for their personal use, not for research and development purposes. The findings of the study reflect Zwilling et al. (2020) who have shown that the computer software skills among the study respondents are also moderate. The results of the study are however slightly different than those of Nor Zaira et al. (2016), who found that teachers' level of ICT skills is low. The 
study states that the ICT skills of teachers and ICT facilities are key factors affecting the use of VLE Frog among secondary school teachers. This is another option which also affects the skills of students in the use of Frog VLE.

The results of the analysis of Frog VLE show that the use of Frog VLE in mathematical education for fifth-year students is moderate. This shows that the Frog VLE application is still not fully used in mathematical learning. The level of knowledge and skills of students in the Frog VLE can influence this. According to a study by Nor Zaira et al (2016), the ICT skills and the ICT facilities of teachers in secondary schools are one of the main factors that influence the use of VLE Frog. Based on the study, it can be concluded that the level of use of Frog VLE students in mathematics learning is also influenced by their knowledge and skills on the application.

\section{Knowledge and Skills on Frog VLE and Its Application in Mathematics Learning Based on Gender}

The results demonstrate that the average knowledge of male and female students varies significantly. Five years of student knowledge in Frog VLE has been shown to be better than men. The female students have a high level of knowledge of Frog VLE. This disparity in knowledge levels could be attributed to female students' greater focus on the knowledge imparted by the teacher during class. This is consistent with the findings of the Nor Zaira et al. (2016) study, which found gender differences in the level of use of VLE Frog among teachers who teach. The analysis results show that female teachers use VLE Frog more than male teachers. Alzeebaree and Hasan (2020).) discovered that female trainee teachers at public universities were less knowledgeable about computers than male trainee teachers.

The findings show that there is no difference in the skills of male and female Frog VLE students. This means that gender has no effect on students' skill levels. According to the findings, while female students' knowledge of Frog VLE is superior to male students' knowledge, both male and female students' skills on Frog VLE are at the same level. This could be because female students aren't using their knowledge in the Frog VLE application.

As a result, it must be reconsidered whether female students' knowledge does not assist them in improving their Frog VLE application skills. This could be due to a lack of application, causing skills to stagnate despite having extensive knowledge of the application. As a result, it is critical for teachers to ensure that their students use Frog VLE to further enhance the skills that will entice them to use the application on their own. However, these findings differ slightly from those of Perienen (2020), who found that the percentage of ICT users is low. Although the findings of this study indicate a slight increase in the level of use of Frog VLE, this demonstrates that the digital divide remains an issue in rural areas. Although internet technology and facilities are improving in rural areas, knowledge and skills in using technology are still lacking.

As a result, the school, in collaboration with educators, must provide exposure to the knowledge and skills of using Frog VLE, allowing students to learn independently. Efforts to close the digital divide and develop community ICT skills are long-term goals that must be realised through sound policies and strong government backing (Perienen (2020). 


\section{Relationship of Knowledge and Skills to Frog VLE and Its Use in Mathematics Learning}

The Pearson correlation analysis results show that there is a significant relationship between Frog VLE application knowledge and skills and the use of Frog VLE in mathematics learning. According to the findings, there is a moderately positive relationship (Cohen 1988) between knowledge of Frog VLE application and use of Frog VLE in mathematics learning. Concerning the skill variables, the findings indicate a strong positive relationship (Cohen 1988) between Frog VLE application skills and the use of Frog VLE in mathematics learning. This implies that the greater the students' knowledge and skills of the Frog VLE application, the greater their proclivity to use the Frog VLE application.

According to the findings of this study, a student who has good knowledge and skills of Frog VLE will prefer to use the application as a learning medium. Meanwhile, students who consistently use Frog VLE in their learning will improve their knowledge and skills on the application. This is supported by the findings of Alkan and Meinck (2016), who discovered a significant positive relationship between students' ICT use and ICT literacy. The findings also show that students who consistently use ICT in social communication have a high ICT score and level of skill. Thus, the implications of Frog VLE knowledge and skills that students require in school can be seen in its use outside of school.

Furthermore, the findings of the Chen and $\mathrm{Hu}(2020)$ study show a significant positive relationship between the level of ICT skills and the level of use of VLE Frog. These findings indicate that when teachers' ICT skills are high, so is their use of VLE Frog. On the other hand, if teachers' ICT skills are low, they are less likely to use VLE Frog. This demonstrates the importance of Frog VLE knowledge and skills in increasing the platform's use as a learning medium that aids in the learning of mathematics in a more meaningful way.

\section{Conclusion}

The importance of this study is to be able to provide feedback to the Kelantan NRD, particularly the Technology Development Division and the school, in order to identify the level of knowledge and skills in the use of Frog VLE among rural primary school students in Kelantan. As a result, they will be able to plan the necessary steps to increase the use of Frog VLE by all parties involved.

A quasi-experimental study is proposed for further investigation to determine the effectiveness of the use of Frog VLE in mathematics learning. Also, broaden the scope of the study to examine students' attitudes and motivations toward the use of Frog VLE in mathematics learning. The study's discussion has also revealed the significance of knowledge, skills, and the use of Frog VLE in mathematics learning. As a result of the findings of this study, it is possible to conclude that the level of knowledge and skills on Frog VLE will have a positive impact on increasing the use of Frog VLE in student learning, which will have an impact on academic achievement.

Hence, the findings of the study contribute to a significant theoretical aspect that lead to the betterment of students' learning using technology. This has to considered by the related parties when developing learning technology-based tool especially in mathematics education. Focusing solely on tools will not make the learning of mathematics successful yet feedback from students on the technology tool has to be taken into account as well. Having said that, the contextual contribution plays vital role in terms of the integration of technology in mathematics teaching and learning processes. 


\section{Acknowledgement}

This research was funded by the Faculty o Education, Universiti Kebangsaan Malaysia, GG2020-016

\section{References}

Alzeebaree, Y., \& Hasan, I. A. (2020). What makes an effective EFL teacher: High School Students' Perceptions. Asian ESP Journal, 16(2), 169-183.

Alkan, M., \& Meinck, S. (2016). The relationship between students' use of ICT for social communication and their computer and information literacy. Large-scale Assessments in Education, 4(1), 15.

Barker, J., \& Gossman, P. (2013). The Learning Impact of a Virtual Learning Environment: Students' views. Teacher Advancement Network Journal, 5(2).

Creswell, J. W. (2012). Educational research: Planning, conducting, and evaluating quantitative and qualitative research. Educational Research, pp.Vol. 4. doi:10.1017/СВ09781107415324.004

Chen, X., \& Hu, J. (2020). ICT-related behavioral factors mediate the relationship between adolescents' ICT interest and their ICT self-efficacy: evidence from 30 countries. Computers \& Education, 159, 104004.

Chua, Y. P. (2014). Asas Statistik Penyelidikan. McGraw-Hill Education (Asia).

Fahad, M. A., \& Irfan, N. U. (2016). Web 2.0 Tools and the Development of Cooperative Learning and Higher Order Thinking in the Saudi Higher Education Institutions, International Journal of Internet of Things, Vol. 5 No. 1, pp. 29-36.

Fraenkel, J. R., \& Wallen, E. W. (2006). How to design and evaluate research in education. Boston, MA: McGraw-Hill.

Jackson, S. L. (2006). Research Methods and Statistics. A critical thinking approach. 2nd Edition. USA: Thomson Wadsworth

Kementerian Pendidikan Malaysia. (2013). Pelan Pembangunan Pendidikan Malaysia 20132025 (Pendidikan Prasekolah hingga Lepas Menengah). Putrajaya: Kementerian Pendidikan Malaysia.

Kindsiko, E., Aidla, A., Poltimäe, H., \& Türk, K. (2020). They only teach us word and excel!. Trames, 24(74/69), 1-53.

Lepp, L., Aaviku, T., Leijen, Ä., Pedaste, M., \& Saks, K. (2021). Teaching during COVID-19: The Decisions Made in Teaching. Education Sciences, 11(2), 47.

Mahizer, H., \& Mohd, A. Y. (2016). Frog VLE (persekitaran pembelajaran maya) dalam pengajaran dan pembelajaran: Penerimaan dan kaedah pelaksanaannya. Frog VLE (virtual learning) in teaching and learning: Acceptance and its implementation. Journal of Research, Policy \& Practice of Teachers \& Teacher Education (JRPPTTE). Vol. 6, Issue 2: $67-77$.

Lechien, J. R., Bobin, F., Muls, V., Thill, M. P., Horoi, M., Ostermann, K., ... \& Saussez, S. (2020). Validity and reliability of the reflux symptom score. The Laryngoscope, 130(3), E98E107.

Norazilawati, A., Noraini, M. N., Azmah, N. Y., \& Rosnidar, M. (2013). Aplikasi Persekitaran Pengajaran Maya (FROG VLE) Dalam Kalangan Guru Sains. Jurnal Pendidikan Sains \& Matematik Malaysia, 3(2), 63-76.

Ashikin, N. I., \& Kamisah, O. (2017). Kesan Frog VLE Secara Pembelajaran Kooperatif Terhadap Pencapaian, KBAT dan Minat Pelajar Bagi Subjek Kimia. Seminar on Transdisiplin Education (STEd2017), 635-649. Fakulti Pendidikan, UKM. 
Nooriza, K., \& Effandi, Z. (2015). Integrasi Kemahiran Berfikir Aras Tinggi dalam Pengajaran dan PembelajaranMatematik: Analisis Keperluan Guru. Persidangan Serantau Siswazah Pendidikan

Pallant, J. (2010). SPSS Survival Manual: A step-by-step guide to data analysis using SPSS $4^{\text {th }}$ Edition. Australia: Allen \& Unwin

Perienen, A. (2020). Frameworks for ICT Integration in Mathematics Education-A Teacher's Perspective. Eurasia Journal of Mathematics, Science and Technology Education, 16(6), em1845

Romero-Tena, R., Lopez-Lozano, L., \& Gutierrez, M. P. (2020). Types of Use of Technologies by Spanish Early Childhood Teachers. European Journal of Educational Research, 9(2), 511-522.

Ummu Salma, M., \& Fariza. K. (2014). Tahap Pengetahuan Guru Sekolah Rendah dalam Penggunaan VLE-Frog untuk Pengajaran \& Pembelajaran. The $4^{\text {th }}$ International Conference on Learner Diversity (ICELD 2014), 17-18 September 2014, 780-788.

Van Horn, R. (2007). Educational games. Phi Delta Kappan, 89 (1), 73-74

Zwilling, M., Klien, G., Lesjak, D., Wiechetek, Ł., Cetin, F., \& Basim, H. N. (2020). Cyber security awareness, knowledge and behavior: a comparative study. Journal of Computer Information Systems, 1-16. 